\title{
Nortere 藪田基金補助による研究小集会報告
}

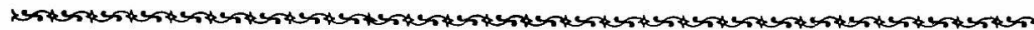

\section{M.C. Liu 教授講演会事後報告}

世話人 水光正仁, 中津誠一郎

M. C. Liu 教授講演会は平成元年 6 月 28 日 (水) 午後 2 時より, 宮崎大学農学部 109 講義室において, 開催さ れた. 演題は「硫酸化チロシン蛋白質の機能に関する研 究」で, 参加者は農学部教官, 大学院, 学部学生および 宮崎医科大学教官を含め, 約 100 名であった. M. C. Liu 博士は現在オクラホマ大学理学部生化学教室の教授 で, ジョージア大学で Ph. D. を取得後ロックフェラー 大学リップマン教授のもとで 1983〜1986 年にかけて硫 酸化チロシン蛋白質に関する研究に従事し, 以来それま で知られていた蛋白質のリン酸化とは異なる代謝制御の 新領域を開拓中で, 顕著な業績を挙げられている.

今回, 本学に国際学術共同研究科研究費予備打ち合せ のため来日されたので, それを機会に本学と九州大学 (向井純一郎教授のお世話) で講演された。

講演会では, まず蛋白質の翻訳後の修飾としてのチロ シンのリン酸化の細胞増殖または代謝制御における重要 な役割を説明され，その分子的類似性のチロシンの硫酸 化の発見の経緯扣よびその分析法, 既知の硫酸化チロシ ン蛋白質, 癌化との関係, 機能, そして分泌過程の新概 念の紹介をされた.

1980 年代前半まで全く注目されなかった蛋白質中の チロシンーO-硫酸の同定法が確立すると, いろいろな蛋

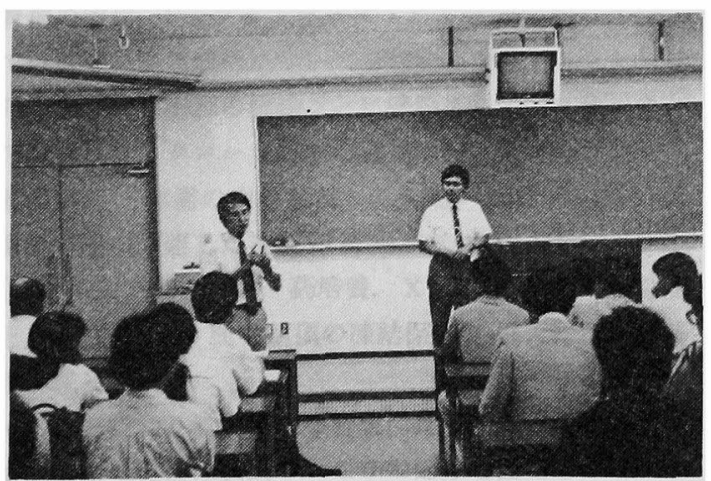

講 演会場 風 景
白質中にチロシンーO-硫酸化が起こっていることが明ら かになった. Liu 博士等は正常細胞と癌細胞の蛋白質中 の硫酸化チロシンを定量したところ，癌細胞では正常細 胞に比べて劇的に（8倍）低くなっていることを明らか にし、リン酸化チロシンと全く逆の現象を発見した. そ してその硫酸化抑制機構をほぼ明らかにした，また硫酸 化は蛋白質中のチロシン上で特異的に起きているのか, または非特異的に起きているのかを調べるため, フィブ ロネクチンをモデル蛋白質として調べたところ，特異的 にカルボキシル基末端, フィブリン結合ドメインの 1 個 のチロシンだけが硫酸化されていることを明らかにし た.また細胞中の硫酸化チロシン蛋白質の異化代謝は早 く, 細胞外にフリーの硫酸化チロシンとして出て行くこ とも明らかにした．しかしチロシン硫酸化の生化学的意 義は今のところ不明であるので，脱硫酸化フィブロネク チンを調製しそのアフィニティ活性を調べたところゼラ チン, またはへパリンに対する結合能力は変らないが, フィブリンに対しては激減することを明らかにし，硫 酸化の蛋白質の立体構造へ対する重要な影響およびそれ に伴う機能制御の可能性を提案した. 一方, 蛋白質のチ ロシン硫酸化は分泌のためのシグナルとも考它られてい る. 蛋白質のチロシン硫酸化は細胞内ゴルジ体 (trans). の硫酸転移酵素により行われ，小胞となり細胞外に分泌 されると理解されている. Liu 博士等は, 細胞内ゴルジ 体にチロシン硫酸化酵素の存在とまたチロシン硫酸化蛋 白質の結合蛋白質（レセプター）の存在を明らかにし た.このレセプターは硫酸化チロシン蛋白質に特異的に 結合し, pH 5.5 で解離し, リン酸化チロシン蛋白質, ま たは他のアミノ酸には全く結合しなかった.これらのこ とより，硫酸化チロシン蛋白質の分泌経路の新しい概念 が提案された．また，既知の硫酸化チロシン蛋白質のア ミノ酸配列から，チロシン硫酸化が起こるためには粼の アミノ酸に酸性アミノ酸と疎水性了ミノ酸を必要とする ことを明らかにされ，レセプター蛋白質も同様なアミノ 酸配列を必要としこれらのことからレセプター蛋白質 と基質硫酸化チロシン蛋白質の結合阻害剤 $N$-アセチル チロシンーOー硫酸を発見された。

蛋白質の硫酸化に関する研究は世界でも数少なく，と くに硫酸化チロシンの機能解明は新しい研究テーマで, 
きわめて重要な課題になっている. また遺伝子工学の分 野です翻訳後の蛋白質の修飾汸機能発現にきわめて重要 であることが明らかにさ机ており，本硫酸化すその一つ である. 現在, 宮崎大学農学部生物化学研究室と共同研
究中でである.

今回の Liu 博士の講演は最近注目されている蛋白質 学の基礎研究であり，最先端の研究を如実に紹介され, 出席者に強い刺激を与えた。 